\title{
PENERAPAN SANKSI PIDANA TERHADAP PELAKU PERKAWINAN POLIGAMI DALAM PERSFEKTIF PERUNDANG-UNDANGAN INDONESIA
}

\author{
Oleh : \\ Sri Roslinda* \\ Bunyamin Alamsyah* \\ Ferdricka Nggeboe *
}

\begin{abstract}
ABSTRAK
Berbagai sikap pro kontra yang diberikan masyarakat terhadap pelaku poligami baik dari kalangan perempuan ataupun dari kalangan pria, dan tidak sedikit yang menentang perilaku poligami, namun tidak sedikit pula yang mendukung praktek poligami. Sewaktu sebuah perkawinan poligami dilakukan di luar ketentuan hukum yang berlaku berarti norma-norma hukum tentang poligami telah dilanggar oleh orang-orang yang bersangkutan. Dengan demikian akan menimbulkan konsekuensi hukum yang berupa sanksi pidana. Merujuk kepada Undang-Undang Perkawinan, jelas tidak memberikan sanksi pidana terhadap pelaku perkawinan poligami karena tidak memuat ketentuan pidananya karena orang-orang yang melakukan poligami tanpa melalui prosedur yang telah ditetapkan oleh Undang-undang perkawinan. Namun pengaturan perkawinan poligami yang tidak sesuai dengan aturan hukum Undang-Undang Perkawinan tersebut diatur di dalam Kitab Undang-undang Hukum Pidana (selanjutnya disebut KUHP) yang mana perbuatan tersebut disebut tindak pidana perkawinan. Melalui karya ilmiah memberikan tujuan menjelaskan menganalisis penerapan sanksi pidana terhadap pelaku perkawinan poligami dalam perspektif perundang-undangan Indonesia dan hambatan dalam penerapan sanksi pidana terhadap pelaku perkawinan poligami.
\end{abstract}

Kata Kunci: Sanksi Pidana, Pelaku Poligami

\section{A. Latar Belakang Masalah}

Perkawinan merupakan peristiwa penting dalam kehidupan setiap manusia. Perkawinan yang terjadi antara seorang pria dengan seorang wanita akan menimbulkan akibat lahir maupun batin terhadap kehidupan mereka sebagai suami isteri, terhadap kualitas dan masa depan anak-anak yang mereka lahirkan dan besarkan, terhadap masyarakat, dan terhadap masa depan bangsa dan negara.

Pendapat mengenai hal itu, antara lain dikemukakan oleh Lili Rasjidi. Ia menjelaskan bahwa

\footnotetext{
* Hakim di MA RI, Alumni Program Magister Ilmu Hukum Unbari.

* Pengajar Program Magister Ilmu Hukum Unbari.

* Pengajar Program Magister Ilmu Hukum Unbari.
} 
"Dalam bentuknya yang terkecil, hidup bersama itu dimulai dengan adanya keluarga. Lembaga perkawinan merupakan dasar peradaban umat manusia dan tempat bagi manusia untuk mengabadikan diri satu sama lain dan saling menghormati perasaan". ${ }^{1}$

Dengan demikian, dapat dikatakan bahwa terdapat korelasi yang kuat antara kualitas perkawinan dengan kualitas keluarga yang akan terbentuk dari perkawinan tersebut. Kualitas keluarga itulah yang pada gilirannya akan menentukan kualitas sebuah bangsa.

Karena perannya yang demikian penting sebagai fondasi dasar kehidupan sebuah bangsa, tidaklah mengherankan manakala perkawinan dan segenap masalah yang menyertainya, menjadi perhatian utama dalam hubungan antar manusia, baik dalam sudut pandang agama, maupun dalam perspektif sosial dan budaya.

Menurut Musthafa Kamal, diantara sekian masalah yang menyangkut hubungan antar manusia atau dalam perspektif Agama Islam dikenal dengan istilah muamalat duniawiyat, masalah perkawinan (munakahat) dengan segala persoalan yang berada di sekitarnya mendapatkan perhatiannya yang istimewa. ${ }^{2}$

Oleh karena itu, dapat pula difahami manakala negara mengatur secara khusus segala sesuatu yang menyangkut penyelenggaraan perkawinan. Dalam perspektif perundang-undangan Indonesia, penyelenggaraan perkawinan diatur di dalam UndangUndang Nomor 1 Tahun 1974 tentang Perkawinan (selanjutnya disebut Undang-Undang Perkawinan).

Undang-Undang yang disahkan di Jakarta pada tanggal 2 Januari 1974, dan ditempatkan pada Lembaran Negara Republik Indonesia Tahun 1974 Nomor 1 tersebut, lahir berdasarkan pertimbangan bahwa bahwa sesuai dengan falsafah Pancasila serta citacita untuk pembinaan hukum nasional, perlu adanya Undang-Undang tentang Perkawinan yang berlaku bagi semua warga negara. Artinya, bagi suatu negara dan bangsa seperti Indonesia, adalah mutlak adanya Undang-Undang Perkawinan yang bersifat Nasional yang sekaligus menampung prinsip-prinsip dan memberikan landasan hukum perkawinan yang selama ini menjadi pegangan dan telah berlaku bagi berbagai golongan suku dan agama diIndonesia.

${ }^{1}$ Lili Rasjidi, Hukum Perkawinan dan Perceraian di Malaysia dan di Indonesia. PT. Remaja Rosdakarya. Bandung. 1991. hal. 1.

${ }^{2}$ Musthafa Kamal dkk, Fikh Islam, Citra Karsa Mandiri, Yogyakarta, 2002, hal. 243. 
Undang-Undang Perkawinan mulai berlaku secara efektif pada tanggal 1 Oktober 1975, bersamaan dengan disahkannya Peraturan Peraturan Pemerintah Republik Indonesia Nomor 9 Tahun 1975 Tentang Pelaksanaan Undang-Undang Nomor 1 Tahun 1974.

Merujuk pada Penjelasan Umum Undang-Undang Perkawinan, dapat disimpulkan bahwa Undang-Undang Perkawinan merupakan unifikasi dalam bidang hukum perkawinan bagi seluruh warga negara Indonesia. Secara historis, sebelum diberlakukannya UndangUndang Perkawinan, berlaku berbagai hukum perkawinan bagi berbagai golongan warganegara dan berbagai daerah seperti berikut :

a. bagi orang-orang Indonesia asli yang beragama Islam berlaku hukum agama yang telah diresiplir dalam Hukum Adat;

b. bagi orang-orang Indonesia asli lainnya berlaku Hukum Adat;

c. bagi orang-orang Indonesia asli yang beragama Kristen berlaku Huwelijksordonnantie Christen Indonesia (S. 1933 Nomor 74);

d. bagi orang Timur Asing Cina dan warganegara Indonesia keturunan Cina berlaku ketentuan-ketentuan Kitab Undang-Undang Hukum Perdata dengan sedikit perubahan;

e. bagi orang-orang Timur Asing lain-lainnya dan warganegara Indonesia keturunan Timur Asing lainnya tersebut berlaku hukum Adat mereka;

f. bagi orang-orang Eropa dan Warga negara Indonesia keturunan Eropa dan yang disamakan dengan mereka berlaku Kitab Undang-Undang Hukum Perdata.

Sebagai Undang-Undang yang bersifat unifikasi dan sesuai dengan landasan falsafah Pancasila dan Undang-Undang Dasar 1945, maka Undang-Undang Perkawinan di satu pihak harus dapat mewujudkan prinsip-prinsip yang terkandung dalam Pancasila dan Undang-Undang Dasar 1945, sedangkan di lain pihak harus dapat pula menampung segala kenyataan yang hidup dalam masyarakat. Undang-Undang Perkawinan ini telah menampung di dalamnya unsur-unsur dan ketentuan-ketentuan Hukum Agama dan Kepercayaan itu dari masing-masing warga negara.

Di dalam Pasal 1 Undang-Undang Perkawinan, ditegaskan mengenai tujuan dari dilaksanakannya sebuah perkawinan, bahwa 
"Perkawinan ialah ikatan lahir bathin antara seorang pria dengan seorang wanita sebagai suami isteri dengan tujuan membentuk keluarga (rumah tangga) yang bahagia dan kekal berdasarkan Ketuhanan Yang Maha Esa”.

Untuk mencapai tujuan hakiki dari perkawinan tersebut, maka Undang-Undang Perkawinan menentukan prinsip-prinsip atau asas-asas mengenai perkawinan dan segala sesuatu yang berhubungan dengan perkawinan yang telah disesuaikan dengan perkembangan dan tuntutan zaman. Asas-asas atau prinsip-prinsip tersebut adalah sebagai berikut

a. Tujuan perkawinan adalah membentuk keluarga yang bahagia dan kekal. Untuk itu suami isteri perlu saling membantu dan melengkapi, agar masingmasing dapat mengembangkan kepribadiannya membantu dan mencapai kesejahteraan spirituil dan materiil;

b. Dalam Undang-Undang ini dinyatakan, bahwa suatu perkawinan adalah sah bilamana dilakukan menurut hukum masing-masing agamanya dan kepercayaannya itu; dan di samping itu tiap-tiap perkawinan harus dicatat menurut peraturan perundang-undangan yang berlaku. Pencatatan tiap-tiap perkawinan adalah sama halnya dengan pencatatan peristiwa-peristiwa penting dalam kehidupan seseorang, misalnya kelahiran, kematian yang dinyatakan dalam Surat-surat keterangan, suatu akte resmi yang juga dimuat dalam daftar pencatatan;

c. Undang-Undang ini menganut asas monogami. Hanya apabila dikehendaki oleh yang bersangkutan, karena hukum dan agama dari yang bersangkutan mengizinkannya, seorang suami dapat beristeri lebih dari seorang. Namun demikian perkawinan seorang suami dengan lebih dari seorang isteri, meskipun hal itu dikehendaki oleh pihak-pihak yang bersangkutan, hanya dapat dilakukan apabila dipenuhi berbagai persyaratan tertentu dan diputuskan oleh Pengadilan;

d. Undang-Undang ini menganut prinsip, bahwa calon suami-isteri itu harus telah masak jiwa raganya untuk dapat melangsungkan perkawinan, agar supaya dapat mewujudkan tujuan perkawinan secara baik tanpa berakhir pada perceraian dan mendapat keturunan yang baik dan sehat. Untuk itu harus dicegah adanya perkawinan antara calon suami-isteri yang masih di bawah 
umur. Di samping itu, perkawinan mempunyai hubungan dengan masalah kependudukan. Ternyatalah bahwa batas umur yang lebih rendah bagi seorang wanita untuk kawin, mengakibatkan laju kelahiran yang lebih tinggi jika dibandingkan dengan batas umur yang lebih tinggi.Berhubung dengan itu, maka Undang-Undang ini menentukan batas umur untuk kawin baik bagi pria maupun bagi wanita, ialah 19 (sembilan belas) tahun bagi pria dan 16 (enam belas) tahun bagi, wanita.

e. Karena tujuan perkawinan adalah untuk membentuk keluarga yang bahagia kekal dan sejahtera, maka Undang-Undang ini menganut prinsip untuk mempersukar terjadinya perceraian. Untuk memungkinkan perceraian, harus ada alasan-alasan tertentu serta harus dilakukan di depan Sidang Pengadilan.

f. Hak dan kedudukan isteri adalah seimbang dengan hak dan kedudukan suami baik dalam kehidupan rumahtangga maupun dalam pergaulan masyarakat, sehingga dengan demikian segala sesuatu dalam keluarga dapat dirundingkan dan diputuskan bersama oleh suamiisteri.

Berdasarkan perumusan ketentuan mengenai tujuan mendasar dari perkawinan, dan prinsip-prinsip atau asas perkawinan di dalam Undang-Undang Perkawinan di atas, dapat dilihat dengan jelas komitmen dan keinginan yang kuat dari negara untuk menjadikan perkawinan sebagai pintu gerbang membentuk keluarga yang harmonis, utuh dan bahagia lahir batin, sebagai fondasi terbentuknya bangsa yang kuat, berdaya saing dan memiliki peradaban yang tinggi.

Undang-undang Perkawinan menganut asas monogami, yaitu suatu perkawinan antara seorang pria dan seorang wanita sebagai isteri dan seorang wanita hanya boleh mempunyai seorang suami. Namun demikian, undang-undang ini juga membuka kemungkinan seorang pria mempunyai lebih seorang isteri atau poligami. ${ }^{3}$

Dalam suatu kehidupan perkawinan tercipta suatu kelompok baru yang disisi dengan suami dan istri serta anak-anak yang terlahir dari suatu perkawinan yang dilakukan dengan cara yang dibenarkan oleh norma, baik itu norma agama, norma susila dan norma hukum. Suatu kehidupan rumah tangga, untuk terciptanya suatu keluarga yang sakinah (pondasi) mawaddah (kasih sayang) dan warahmah (kewajiban) harus ada keseimbangan

${ }^{3}$ Martiman Projohamidjojo, Hukum Perkawinan Indonesia, Indonesia Legal Center Publishing, Jakarta, 2007, hal. 10 
tugas antara suami, istri dan anak-anak. Ketentraman hidup dalam rumah tangga menjadi suatu cita-cita yang harus dicapai dalam kehidupan berkeluarga.

Untuk terciptanya suatu ketentraman dalam rumah tangga, maka harus ada rasa kasih sayang, rasa kebersamaan, kesenangan dan saling percaya. Namun, ketika dalam suatu kehidupan perkawinan itu diisi dengan banyak kebohongan dan tidak adanya rasa kebersamaan, kasih sayang dan harga menghargai maka akan terciptalah suatu pertengkaran yang bisa mengakibatkan banyak hal, baik itu pertengkaran, perceraian dan bahkan poligami.

Berbagai sikap pro kontra yang diberikan masyarakat terhadap pelaku poligami baik dari kalangan perempuan ataupun dari kalangan pria, dan tidak sedikit yang menentang perilaku poligami, namun tidak sedikit pula yang mendukung praktek poligami.Sebagian masyarakat yang menentang praktek poligami memfokuskan pokok permasalahan kepada kemaslahatan wanita baik dari segi mental maupun keadilan.

Aspek mental yang menjadi alasan kaum wanita menentang poligami dikarenakan praktek poligami menimbulkan perasaan superior dan inperior antara suami dan isteri mudanya dengan isteri tuanya disamping tumbuhnya rasa ketergantungan ekonomi isteri tuanya kepada suaminya, yang timbul akibat kurangnya rasa keadilan dari segi perasaan yang abstrak ataupun memang dikarenakan suami tidak dapat mewujudkan keadilan dari segi ekonomi itu sendiri.

Kalangan masyarakat yang mendukung poligami lebih memfokuskan diri kepada aspek hukum agama yang membolehkan praktek poligami sampai dengan isteri keempat jika suami sanggup menafkahi dan mampu berlaku adil terhadap isteri-isterinya.

Mereka berpahaman bahwa pernikahan poligami masih dalam wilayah ibadah, yang ketentuan rukun dan syarat pernikahannya diatur dalam hukum agama, dan para pendukung poligami merasa tidak wajar jika poligami dilarang oleh negara apalagi mengancam pelaku poligami ilegal dengan sanksi pidana dalam kategori kejahatan ringan (rechtsdeliktern).

Sewaktu sebuah perkawinan poligami dilakukan di luar ketentuan hukum yang berlaku berarti norma-norma hukum tentang poligami telah dilanggar oleh orang-orang yang bersangkutan. Dengan demikian akan menimbulkan konsekuensi hukum yang berupa sanksi pidana.

Merujuk kepada Undang-Undang Perkawinan, jelas tidak memberikan sanksi pidana terhadap pelaku perkawinan poligami karena tidak memuat ketentuan pidananya 
karena orang-orang yang melakukan poligami tanpa melalui prosedur yang telah ditetapkan oleh Undang-undang perkawinan. Namun pengaturan perkawinan poligami yang tidak sesuai dengan aturan hukum Undang-Undang Perkawinan tersebut diatur di dalam Kitab Undang-undang Hukum Pidana (selanjutnya disebut KUHP) yang mana perbuatan tersebut disebut tindak pidana perkawinan.

Tindak pidana atau perbuatan pidana adalah perbuatan yang oleh aturan hukum pidana dinyatakan sebagai perbuatan yang dilarang. ${ }^{4}$ Menurut wujudnya atau sifatnya, perbuatan-perbuataan pidana adalah perbuatan-perbuatan yang melawan hukum. Perbuatan-perbuatan ini juga merugikan masyarakat dalam arti bertentangan atau menghambat akan terlaksananya tata dalam pergaulan masyarakat yang dianggap baik dan $\operatorname{adil}^{5}$

Hukum pidana adalah bagian dari hukum yang mengadakan dasar dan aturanaturan untuk menentukan perbuatan-perbuatan mana yang tidak boleh dilakukan, yang dilarang dengan disertai ancaman sanksi berupa suatu pidana tertentu, bagi barang siapa yang melanggar larangan tersebut, menentukan kapan dan dalam hal apa kepada mereka yang melanggar larangan-larangan itu dapat dikenakan atau dijatuhi pidana sebagaimana yang telah diancamkan, menentukan dengan cara bagaimana pengenaan pidana itu dapat dilaksanakan apabila orang yang disangka telah melanggar larangan tersebut. ${ }^{6}$

Pasal 279 KUHP menyatakan bahwa

(1). Dihukum penjara selama-lamanya 5 tahun:

1e. Barang siapa yang kawin sedang diketahuinya, bahwa perkawinannya yang sudah ada menjadi halangan yang sah baginya akan kawin lagi.

2e. Barang siapa yang kawin, sedang diketahuinya, bahwa perkawinan yang sudah ada dari pihak yang lain itu akan menjadi halangan yang sah bagi pihak yang lain itu akan kawin lagi.

(2). Kalau orang yang bersalah karena melakukan perbuatan yang diterangka di 1e, menyembunyikan kepada pihak lain, bahwa perkawinannya yang sudah ada itu menjadi halangan yang sah akan kawin lagi, dihukum penjara selama-lamanya 7 tahun.

${ }^{4}$ Arif Gosita, Masalah Korban Kejahatan, Pressindo, Jakarta, 1993, hal. 23

${ }^{5}$ Andi Hamzah, Asas-asas Hukum Pidana, PT Rineka Cipta, Jakarta.1994, hal. 5

${ }^{6}$ Sudarto, 1990,Hukum Pidana I, Yayasan Sudarto, Fakultas Hukum Undip Semarang. hal. 10 
Dalam penjelasan Pasal 279 KUHP, menyatakan bahwa suatu syarat supaya orang dapat dihukum menurut Pasal ini ialah orang itu harus mengetahui dulu ia pernah kawin dan perkawinan ini masih belum dilepaskan atau diceraikan.selanjutnya menurut peraturan pernikahan dalam Kitab Undang-Undang Hukum Perdata, orang yang tidak diperbolehkan kawin untuk kedua kalinya ialah orang yang tunduk pada peraturan itu, yakni orang-orang Eropah, Indonesia, Tionghoa dan lain-lain, yang beragama Kristen. Bagi mereka perkawinan yang pertama itu sudah merupakan halangan yang sah untuk melakukan perkawinan lagi. Dan apabila mereka kawin lagi, dapat dituntut menurut Pasal ini.

Berdasarkan asas Tiada Pidana Tanpa Kesalahan (Geen Straf Zonder Schuld, Actus Non Facit Nisi Mens Sit Rea). Menyatakan pidana hanya diberikan kepada orang yang bersalah, asas ini ada dalam hukum yang tidak tertulis dan hidup serta berkembang dalam anggapan masyarakat. ${ }^{7}$

Berdasarkan hal tersebut seseorang baru dapat dipidana apabila pada diri sipelaku ada unsur kesalahan terhadap pebuatan yang dilakukan dan perbuatan tersebut diatur dalam Undang-Undang. Namun adakalanya seseorang yang melakukan perbuatan pidana yang pada perbuatan tersebut terdapat unsur kesalahan tidak dihukum, hal ini terdapat dalam Pasal 44 KUHP.

Setiap orang yang melakukan perkawinan poligami tanpa melalui prosedur yang telah ditetapkan oleh Undang-Undang dapat dituntut menurut Pasal 279 KUHP. Meskipun demikian perkawinan poligami tidak sesuai dengan aturan Undang-undang atau disebut juga poligami liar yang terjadi di tengah-tengah kehidupan masyarakat yang tidak tersentuh oleh hukum, namun ada juga tindak pidana perkawinan itu dituntut berdasarkan Pasal 279 KUHP tersebut.

Ketika perkawinan menjadi tindak pidana, maka ada beberapa orang yang menjadi pelaku perbuatan tersebut, yaitu suami (laki-laki) dan istri (perempuan). Berdasarkan Pasal 279 KUHP hukuman itu dijatuhkan kepada kedua pelaku tersebut, namun pada pelaksanaannya banyak kasus tindak pidana perkawinan (poligami liar) yang pidananya hanya dijatuhkan kepada pelaku laki-laki saja (suami), sedangkan perempuan (istri kedua) tidak semua perempuan yang melakukan tindak pidana didakwa melakukan perbuatan yang sama.

Selanjutnya didalam Rancangan Kitab Undang-Undang Hukum Acara Pidana pada:

${ }^{7}$ Romli Atmasasmita, 1989,Asas-asas Perbandingan Hukum Pidana, Cetakan Pertama, Yayasan LBH, Jakarta. Hal. 45 
Pasal 463

1. Dipidana dengan pidana penjara paling lama 5 (lima) tahun atau pidana denda paling banyak Kategori IV, setiap orang yang:

a. Melangsungkan perkawinan, padahal diketahui bahwa perkawinan atau perkawinan-perkawinannya yang ada menjadi penghalang yang sah untuk melangsungkan perkawinan tersebut; atau

b. Melangsungkan perkawinan, padahal diketahui bahwa perkawinan atau perkawinan-perkawinan dari pihak lain menjadi penghalang yang sah untuk melangsungkan perkawinan tersebut.

2. Jika pembuat tindak pidana sebagaimana dimaksud pada ayat (1) huruf a menyembunyikan kepada pihak yang lain bahwa perkawinan atau perkawinan-perkawinannya yang ada menjadi penghalang yang sah untuk melangsungkan perkawinan tersebut, maka dipidana dengan pidana penjara paling lama 7 (tujuh) tahun atau pidana denda paling banyak Kategori IV.

Masalah lain yang sering terjadi di masyarakat masih banyak seorang suami yang melakukan poligami secara tidak resmi atau tidak dilakukan didepan petugas pencatat nikah dan Pengadilan Agama, pelaku poligami ini hanya melakukan nikah siri dan ada juga yang melakukan pemalsuan identitas di Kantor Urusan Agama (KUA). Hal ini dilakukan untuk menyembunyikan pernikahannya dari istri sebelumnya karena kemungkinan pelaku poligami tersebut tidak mendapatkan izin dari istri yang sebelumnya. Adapun modus pelaku poligami yang ada dapat berupa menikah dibawah tangan, pemalsuan identitas, nikah tanpa izin isteri pertama, memaksa mendapatkan izin dan tidak diketahui modusnya.

\section{B. Perumusan Masalah}

Adapun pertanyaan-pertanyaan penelitian yang memfokuskan permasalahan di atas adalah:

1. Bagaimanakah Penerapan Sanksi Pidana Terhadap Pelaku Perkawinan Poligami Dalam Perspektif Perundang-undangan Indonesia?

2. Bagaimanakah Hambatan Dalam Penerapan Sanksi Pidana Terhadap Pelaku Perkawinan Poligami?

\section{Metode Penelitian}


1. Tipe Penelitian

Mengacu pada perumusan masalah dan tujuan penelitian tersebut di atas, maka penelitian ini dilakukan dengan menggunakan penelitian hukum yuridis normatif. ${ }^{8}$ Penelitian normatif diambil sebagai pendekatan utama dalam penelitian ini karena yang menjadi perhatian utama adalah ketentuan perundang-undangan yang mengatur mengenai perkawinan.

2. Pendekatan yang Digunakan

Berdasarkan tipe penelitian normatif tersebut di atas, maka pendekatan yang digunakan dalam penelitian ini adalah pendekatan konseptual (conceptual approach), pendekatan perundang-undangan (normative approach) dan pendekatan sejarah (historical approach). ${ }^{9}$

Pendekatan konseptual dilakukan dengan meneliti asas-asas hukum dan teoriteori pemidanaan. Pendekatan perundang-undangan dilakukan dengan meneliti formulasi ketentuan yang mengatur mengenai perkawinan dan perceraian di dalam perundang-undangan yang berhubungan dengan perkawinan, baik berbentuk hukum positif maupun masih berbentuk rancangan. Pendekatan sejarah dilakukan dengan meneliti sejarah pengaturantentang asal muasal terbentuknya Undang-undang Perkawinan.

\section{Pengumpulan Bahan Hukum}

Pengumpulan bahan hukum dilakukan dengan sistem kartu (card system) melalui berbagai sumber hukum, yang terdiri dari :

a. Bahan hukum primer, meliputi Kitab Undang-Undang Hukum Perdata (KUHPerdata), Undang-Undang Republik Indonesia Nomor 1 Tahun 1974 tentang Perkawinan, Peraturan Peraturan Pemerintah Republik Indonesia Nomor 9 Tahun 1975 Tentang Pelaksanaan Undang-Undang Nomor 1 Tahun 1974, dan Surat Edaran Mahkamah Agung tanggal 20 Agustus 1975 No.MA/Pemb.0807, tentang Petunjuk-petunjuk Mahkamah Agung Mengenai Pelaksanaan Undang-Undang Nomor 1 Tahun 1974.

b. Bahan hukum sekunder, meliputi Rancangan Undang-undang KUHP Nasional, Rancangan Undang-undang Perkawinan, buku-buku literatur yang berhubungan

\footnotetext{
${ }^{8}$ Johnny Ibrahim, Teori dan Metodologi Penelitian Hukum Normatif, Bayumedia Publishing, Surabaya, 2007, hal. 45

${ }^{9}$ Peter Mahmud Marzuki, Penelitian Hukum, Kencana Prenada Media Group, Jakarta, 2005, hal. 93
} 
dengan perkawinan dan perceraian, hasil seminar, makalah-makalah, jurnal, majalah hukum dan naskah lain yang ada relevansinya dengan objek yang diteliti;

c. Bahan hukum tertier, meliputi kamus hukum dan ensiklopedia dan tulisan nonhukum lainnya yang ada kaitannya dengan penelitian ini.

\section{Penerapan Sanksi Pidana Terhdap Pelaku Perkawinan Poligami Dalam Perspektif Perundang-Undangan Indonesia}

1. Penerapan Sanksi Pidana Terhadap Pelaku Perkawinan Poligami Dalam Perspektif Perundang-undangan Indonesia.

Sebelum sampai pada pembahasan penerapan sanksi pidana bagi pelaku perkawinan dalam perepektif perundang-undangan terlebih dahulu penulis mengetengahkan asas perkawinan berdasarkan Undang-Undang Nomor 1 Tahun 1974 tentang Perkawinan. Sebagaimana diketahui bahwa Undang-Undang Nomor 1 Tahun 1974 tentang perkawinan menganut asas monogami, namun undang-undang ini membuka kemungkinan seorang pria mempunyai lebih seorang isteri dengan kata lain adalah poligami.

\section{Pasal 3}

1. Pada asasnya dalam suatu perkawinan seorang pria hanya boleh mempunyai seorang isteri. Seorang wanita hanya boleh mempunyai seorang suami.

2. Pengadilan dapat memberi izin kepada seorang suami untuk beristeri lebih dari seorang apabila dikehendaki oleh pihak-pihak yang bersangkutan.

\section{Pasal 4}

1. Dalam hal seorang suami akan beristrei lebih dari seorang sebagaimana tersebut dalam Pasal 3 ayat (2) Undang-undang ini, maka ia wajib mengajukan permohonan kepada Pengadilan di daerah tempat tinggalnya.

2. Pengadilan dimaksud dalam ayat (1) pasal ini hanya memberikan izin kepada seorang suami yang akan beristeri lebih dari seorang apabila:

a. Isteri tidak dapat menjalankan keajibannya sebagai isteri;

b. Isteri mendapat cacat badan atau penyakit yang tidak dapat disembuhkan;

c. Isteri tidak dapat melahirkan keturunan. 


\section{Pasal 5}

1. Untuk dapat mengajukan permohonan kepada Pengadilan, sebagaimana dimaksud dalam Pasal 4 ayat (1) Undang-undang ini, harus dipenuhi syarat-syarat sebagai berikut:

a. Adanya persetujuan dari isteri/isteri-isteri;

b. Adanya kepastian bahwa suami mampu menjamin keperluan-keperluan hidup isteri-isteri dan anak-anak mereka;

c. Adanya jaminan bahwa suami akan berlaku adil terhadap isteri-isteri dan anak-anak mereka

Undang-undang mengisyaratkan bahwa poligami dapat dilakukan bagi seorang pria jika memenuhi persyaratan yang telah ditentukan oleh Undang-Undang Nomor 1 Tahun 1974 tentang Perkawinan sebagaimana disebutkan dalam Pasal 3 ayat (3), Pasal 4 dan Pasal 5. Apabila ketentuan tersebut dilanggar maka pelaku poligami diancam sanksi pidana kategori pelanggaran sebagaimana diatur Pasal 45 Peraturan Pemerintah Nomor 9 Tahun 1975.

Ketentuan sanksi pidana yang diatur didalam Pasal 45 Peraturan Pemerintah Nomor 9 Tahun 1975 merupakan peristiwa pidana yang digolongkan kepada jenis pidana pelanggaran bukan peristiwa pidana yang digolongkan kepada kejahatan ringan. Ancaman sanksi bagi pelaku yang melanggar ketentuan Pasal 3, Pasal 10 ayat (3) dan Pasal 40 Peraturan Pemerintah Nomor 9 Tahun 1975 ini pun tergolong ringan yaitu hanya sanksi dengan ancaman denda setinggi-tingginya Rp. 7.500,- (tujuh ribu lima ratus rupiah).

Berbeda halnya dengan ketentuan sanksi pidana atas perbuatan yang diatur di dalam Pasal 279 KUHP. Ketentuan pasal tersebut memandang perbuatan poligami sebagai perbuatan pidana kategori kejahatan ringan. Unsur-unsur yang terdapat didalam Pasal 279 ayat (1) KUHAP yaitu:

1. Unsur subjektif, yaitu "barang siapa". Barang siapa ini menyebutkan orang sebagai subjek hukum yang dapat dimintai pertanggungjawaban didepan hukum.

2. Unsur objektif, yaitu:

a. Mengadakan perkawinan. Unsur ini menyebutkan seorang suami yang menikah lagi dengan wanita lain yang perkawinannya dipandang sah menurut hukum masing-masing agama dan kepercayaannya itu. 
b. Mengetahui perkawinan-perkawinannya yang ada. Unsur ini menyebutkan seorang suami yang melakukan perbuatan sebagaimana disebut pada huruf (a), tapi ia secara sadar mengetahui bahwa ia sedang dalam ikatan perkawinan.

c. Mengetahui perkawinan-perkawinan pihak lain. Unsur ini menyebutkan calon mempelai pasangannya mengetahui bahwa calon pasangannya masih dalam ikatan perkawinan yang sah.

d. Adanya penghalang yang sah. Unsur ini menyebutkan bahwa kedua calon mempelai memang sudah mengetahui bahwa perkawinan yang akan mereka langsungkan memiliki halangan yang sah, karena calon suaminya dalam ikatan perkawinan yang sah.

Berdasarkan unsur-unsur yang terkandung didalam Pasal 279 KUHP, maka dapat diketahui bahwa Pasal 279 KUHP bukan untuk mengancam atau melarang seorang suami untuk berpoligami, namun pasal ini hanya mengancam perbuatan poligami yang dilakukan secara illegal.

Selanjutnya penulis ketengahkan perbedaan sanksi pidana yang memandang perbuatan poligami illegal sebagaimana diatur dalam Pasal 45 Peraturan Pemerintah Nomor 9 Tahun 1975 dengan Pasal 279 KUHP adalah perbedaan norma-norma dalam ikatan perkawinan yang diadopsi kedalam hukum positif. Pasal 45 Peraturan Pemerintah Nomor 9 Tahun 1975 memandang perbuatan poligami illegal hanya sebagai perbuatan pelanggaran administratif saja, dikarenakan hukum dasar perkawinan membolehkan poligami jika rukun dan syarat nikah sudah terpenuhi.

Sementara itu Undang-Undang Perkawinan memandang perkawinan sebagai perbuatan untuk melaksanakan ibadah, sedangkan pencatatan perkawinan hanyalah bersifat administratif. Ketentuan poligami dipandang sah selama ketentuan agama dan kepercayaannya itu terpenuhi dan apabila perbuatan poligami tersebut dilaksanakan tanpa adanya penetapan izin dari Pengadilan, maka sanksi yang diberikan kepada pelaku poligami yang melanggar ketentuan tersebut dikenakan sanksi dikategorikan pelanggaran.

Akan berbeda jika melihat pelanggaran poligami dari sudut pandang Pasal 279 KUHP. Perbedaan tersebut disebabkan Pasal 279 KUHP memandang perkawinan bukan sebagai pelaksanaan ibadah, melainkan sebagai suatu hubungan perdata .

Selanjutnya berdasarkan data pada Pengadilan Agama Kuala Tungkal juga mencatat mengenai data izin perkawinan poligami yang terjadi di Kabupaten Tanjung 
Jabung Baratdari tahun 2011-2013. Tetapi tidak semua izin perkawinan poligami ini yang dikabulkan. Penolakan ini juga disebabkan karena syarat-syarat poligami yang belum memenuhi persyaratan. Ini dapat dilihat pada tabel berikut ini :

Walaupun Pengadilan Agama memberikan izin untuk berpoligami dengan berbagai persyaratannya, tetapi kenyataan di masyarakat masih banyak seorang suami yang melakukan poligami secara tidak resmi atau tidak dilakukan didepan petugas pencatat nikah dan Pengadilan Agama, pelaku poligami ini hanya melakukan nikah siri dan ada juga yang melakukan pemalsuan identitas di Kantor Urusan Agama (KUA). Hal ini dilakukan untuk menyembunyikan pernikahannya dari istri sebelumnya karena kemungkinan pelaku poligami tersebut tidak mendapatkan izin dari istri yang sebelumnya.

Kasus tindak pidana poligami berawal dari pengaduan istri pertama (istri yang sah) terhadapperbuatan suami yang melakukan poligami tersebut. Umumnya aduantersebut ada karena istri pertama merasa tidak senang atas perbuatan yangdilakukan suaminya menikahi wanita lain tanpa ada izin terlabih dahuludaridia, sehingga dengan demikian para istri pertama melanjutkan aduantersebut.

Beberapa putusan yang ditetapkan terhadap kasus poligami,hukumannya relatif ringan dibandingkan kerugian yang ditimbulkan olehperbuatan tersebut, karugian tersebut bukan hanya di alami oleh istri secara batin saja tetapi juga secara materi, namun hal ini juga berakibat burukterhadap perkembangan anak.

Ketika seorang laki-laki melakukan perkawinan poligami di luar prosedur yang telah ditetapkan dalam Undang-Undang Nomor 1 Tahun 1974,maka perbuatan tersebut merupakan suatu perbuatan pidana yang bertentangandengan Pasal 279 KUHP sehingga pelaku perbuatan tersebut harusdipertanggungjawabakan secara pidana. Pelaku tindak pidanapoligamiseperti yang dinyatakan dalam Pasal 279 KUHP dijatuhi pidana.Pidana (hukuman) yang dijatuhi tersebut berbeda-beda hal ini dilihatberdasarkan cara perbuatan itu dilakukan.

Ini membuktikan bahwa tindakan dalam perkawinan poligami yang dapat dikategorikan sebagai tindak pidana sering terjadi, namun jarang sekali terkuak di permukaan. Selain itu pula perbuatan tersebut sulit sekali disentuh oleh hukum pidana, hal ini tak lepas dari berbagai macam faktor yang melatarbelakanginya baik dikarenakan sanksi hukum yang lemah dan tidak memihak kepada korban, maupun sanksi hukum yang tidak tegas, dan tidak jelas sehingga tidak bisa memberikan efek jera bagi masyarakat, serta pengawasan yang masih sangat minim dari pemerintah dan aparaturpenegak hukum. 
Faktor lain yang mendukung maraknya pelanggaran perkawinan poligami yaitu rendahnya kesadaran dan pemahaman dari masyarakat tentang hukum, ambiguitas dari undangundang tentang perkawinan yang menyebabkan mudahnya para pelaku untuk berdalih atas perbuatan yang dilakukannya.

Dari data di atas, telah jelas bahwa pelaku poligami maupun pelaksana yang membantu terealisasinya perkawinan poligami yang tidak sesuai dari undang-undang adalah suatu tindak pidana yang dapat diancam sanksi pidana. Maka dari itu harus adanyapenegakan hukum yang maksimal guna memberikan perlindungan dan jaminan hukum bagi masyarakat.

2. Hambatan Dalam Penerapan Dalam Penerapan Sanksi Pidana Terhadap Pelaku Perkawinan Poligami.

Hambatan-hambatan yang dihadapi dalam penerapan sanksi pidana terhadap pelaku poligami adalah:

1. Kejelasan tentang keberadaan barang bukti, dalam hal ini adalah surat nikah. Perkawinan kedua yang dilakukan pelaku tindak poligami kebanyakan dilakukan secara di bawah tangan (nikah sirri) sehingga sulit untuk dilakukan pembuktiannya

2. Kejelasan keberadaan dari orang yang menikahkan (wali nikah). Perkawinan poligami ini biasanya dilakukan secara dibawah tangan (kawin sirri), sehingga kejelasan orang yang menikahkan menjadi kendala dalam hal pemanggilan saksi yang akan dimintai keterangan. Pelaku poligami tersebut menyembunyikan identitas orang yang menikahkannya, dikarenakan status dari orang yang menikahkan tersebut bisa berubah dari saksi menjadi tersangka, atau karena telah ada perjanjian yang dilakukan pelaku poligami dengan orang yang akan menikahkan tersebut.

3. Keberadaan dari orang yang menyaksikan bahwa telah dilakukannya perkawinan poligami (saksi nikah). Perkawinan poligami biasanya dilakukan secara tertutup, dan hanya disaksikan oleh orang-orang tertentu. Sehingga suatu perkawinan tersebut hanya disampaikan dan diketahui dari mulut ke mulut saja. Biasanya orang yang menyaksikan dilangsungkannya perkawinan poligami tersebut tidak akan mengaku bahwa mereka adalah saksi nikah, hal ini disebabkan karena mereka takut status mereka menjadi tersangka dan akan terjerat hukum.

4. Unsur-unsur pidana perkawinan poligami susah untuk dipenuhi, hal ini dikarenakan kendala dalam mendapatkan barang bukti dan saksi. Maka dalam Berita Acara 
Pemeriksaan (BAP), penyidik Polri biasanya memasukkan Pasal alternatif yaitu Pasal 284 KUHP tentang perzinahan. Dimana perzinahan terjadi apabila seorang pria dan wanita melakukan hubungan suami istri padahal orang tersebut telah mempunyai suami ataupun istri yang sah dan belum bercerai. Jika unsur tindak pidana poligami tidak dapat dipenuhi, maka bisa dialihkan kepada tindak pidana perzinahan yang termasuk ke dalam kejahatan terhadap kesusilaan.

5. Adanya kebiasaan masyarakat yang menyelesaikan masalah poligami dengan cara damai, sehingga kasus poligami tersebut tidak sampai dilimpahkan pada kejaksaan. Namun hanya selesai pada tingkat penyidikan yang dilakukan oleh penyidik polri.

6. Ketika seorang suami melakukan penghianatan terhadap suatu pernikahan dengan melakukan pernikahan dengan wanita lain tanpa sepengetahuan istri pertama, hal ini merupakan suatu derita yang sangat mendalam bagi korban (istri pertama dan anakanak), namun meskipun hal ini terjadi si istri tidak ingin mengadukan suaminya karena mereka malu kepada tetangga apabila sampai suaminya masuk ke dalam bui, sehingga meskipun pengaduan telah disampaikan, banyak juga diantara istri yang mencabut kembali adua terhadap suami yang melakukan poligami di luar prosedur tersebut

\section{E. Kesimpulan}

Berdasarkan uraian diatas, maka dapat diambil beberapa kesimpulan sebagai berikut:

1. Perkawinan poligami illegal merupakan suatu perbuatan pidana/tindak pidana yang dapat dikategorikan kepada kejahatan terhadap asal-usul pernikahan sehingga dengan demikian pelaku yang melakukan tindak pidana poligami wajib dimintakan pertanggungjawabannya karena perbuatan tersebut merupakan perbuatan yang termasuk kepada delik aduan yang absolute, artinya yang dilarang dari perbuatan tersebut adalah peristiwanya sehingga kasus tersebut harus di periksa secara hukum pidana.

2. Dalam pelaksanaan pertanggungjawaban pidana pelaku tindak pidana poligami, maka terdapat kendala yang ditemui dalam pemeriksaan kasus poligami tersebutt. Mulai dari pemeriksaan saksi sampai adanya penyelesaian kasus tindak pidana poligami dengan cara damai.

\section{F. Rekomendasi}


1. Agar hukuman yang dijatuhkan lebih berat dan menimbulkan efek jeraterhadap si pelaku, sebaiknya diatur ketentuan sanksi pidananya didalam Undang-Undang Perkawinan. Oleh karenanya perlu adanya konsepsi perubahan dalam UndangUndang Perkawinan terkait masalah poligami ini.

2. Agar keluarga pasangan yang akan melangsungkan perkawinan terlebih dahulu menyelidiki dan mengetahui tentang asal usul pasangan yang akan menikah tersebut. Dengan demikian akan mempersempit ruang kejahatan yang akan terjadi bagi para pelaku poligami.

\section{G. Daftar Pustaka}

Lili Rasjidi, Hukum Perkawinan dan Perceraian di Malaysia dan di Indonesia. PT. Remaja Rosdakarya. Bandung. 1991

Musthafa Kamal dkk, Fikh Islam, Citra Karsa Mandiri, Yogyakarta, 2002

Arif Gosita, Masalah Korban Kejahatan, Pressindo, Jakarta, 1993

Andi Hamzah, Asas-asas Hukum Pidana, PT Rineka Cipta, Jakarta.1994

Sudarto, 1990,Hukum Pidana I, Yayasan Sudarto, Fakultas Hukum Undip Semarang.

Romli Atmasasmita, 1989,Asas-asas Perbandingan Hukum Pidana, Cetakan Pertama, Yayasan LBH, Jakarta

Johnny Ibrahim, Teori dan Metodologi Penelitian Hukum Normatif, Bayumedia Publishing, Surabaya, 2007

Peter Mahmud Marzuki, Penelitian Hukum, Kencana Prenada Media Group, Jakarta, 2005 